\title{
STUDI PENAMBAHAN IKAN GABUS (Channa striata) TERHADAP MUTU DENDENG DAUN KATUK (Sauropus androgynus)
}

\author{
Fatimah $^{(1)}$, Retti Ninsix, S.Tp., MP ${ }^{(2)}$, dan Rifni Novitasari, S.Tp., MP ${ }^{(2)}$ \\ ${ }^{(1)}$ Alumni Teknologi Pangan, Faperta UNISI \\ ${ }^{(2)}$ Dosen Teknologi Pangan UNISI, Riau
}

\begin{abstract}
Abstrak
Tujuan dari penelitian ini adalah untuk mengetahui persentase ikan gabus yang tepat seta pengaruhnya terhadap karakteristik penerimaan konsumen serta mutu dendeng daun katuk. Berdasarkan hasil penelitian dendeng daun katuk (Sauropus androgynus) yang ditambahkan dengan ikan gabus (Channa striata) bahwa perlakuan terbaik terdapat pada perlakuan D dengan penambahan ikan gabus $40 \%$ yaitu dengan kadar air 9,19\%, kadar protein 4,46\%, kadar vitamin C 1,36\%. Dengan hasil uji organoleptik tingkat penerimaan konsumen warna 55\%, aroma 2,90\%. Namun pada tekstur panelis lebih menyukai perlakuan A dengan penambahan ikan gabus sebanyak $10 \%$ yaitu $3,45 \%$ sedangkan pada perlakuan B yaitu dengan penambahan ikan gabus sebanyak $20 \%$ yaitu $2,80 \%$.
\end{abstract}

Kata Kunci : Dendeng, Daun Katuk, Ikan Gabus

\section{PENDAHULUAN}

Makanan dendeng sudah dikenal dengan luas di indonesia, bahkan bisa dikategorikan makanan khas nusantara. Kebanyakan dendeng dibuat dari daging sapi yang diawetkan dengan cara dikeringkan dan dijemur dibawah sinar matahari. Pada umumnya dendeng di bumbui dengan asam, garam, dan bumbu rempah-rempah lain. Saat ini dendeng bisa dibuat dengan cara digiling, dipakaikan ragi dan juga di iris tipis.

Namun harga daging sapi sebagai bahan dasar pembuatan dendeng yang terus meningkat menjadi suatu problem tersendiri bagi konsumen maupun pengusaha yang mengolah dendeng berbahan dasar daging, Sehingga masalah pemalsuan produk dendeng sapi yang bercampur dengan daging yang tidak layak bahkan tidak diperbolehkan untuk dikonsumsi. Untuk menghindari hal tersebut dengan adanya pemalsuan dendeng daging sapi yang dicampur dengan daging yang tidak layak bahkan tidak diperbolehkan untuk dikonsumsi, maka sekarang ada olahan inovasi terbaru yaitu dendeng berbahan dasar sayuran.

Sayuran merupakan salah satu bahan pangan yang populer bagi masyarakat Indonesia. Selain mudah diperoleh, murah harganya serta dapat diolah menjadi berbagai hidangan yang lezat, sayuran juga banyak mengandung komponen antioksidan seperti asam askorbat, karotenoid, flavonoid, melanoidin, asam organik tertentu, zat pereduksi, peptida, tanin dan tokoferol. Antioksidan tersebut dapat berfungsi sebagai senyawa pereduksi, menangkap senyawa radikal, mengikat ion logam pro-oksidan dan penghambat terbentuknya singlet oksigen (Mulyadi, 1995). 
Sayuran biasanya dikonsumsi oleh masyarakat Indonesia dalam bentuk lalapan ataupun setelah melalui proses pemasakan seperti perebusan, pengukusan dan penumisan. Pemasakan merupakan salah satu proses pengolahan menggunakan panas. Pemasakan selain dapat meningkatkan daya cerna, cita rasa dan membunuh mikroorganisme patogen, juga dapat mempengaruhi kandungan zat gizi makanan (Mulyati, 1994).

Banyak sayuran yang memiliki manfaat bagi tubuh, salah satunya adalah tanaman katuk (Sauropus androgynus L.Merr.) telah lama dikenal masyarakat Indonesia sebagai tanaman sayuran dengan kandungan gizi yang cukup tinggi. Kandungan nutrien per 100 gram katuk mengandung kalori 59 kal., protein $4.8 \mathrm{~g}$, lemak $1 \mathrm{~g}$, karbohidrat $11 \mathrm{~g}$, kalsium $204 \mathrm{mg}$, fosfor $83 \mathrm{mg}$, besi 2.7 mg, vitamin A 10370 SI, vitamin B1 0.1 $\mathrm{mg}$, vitamin C $239 \mathrm{mg}$, air 81 g b.d.d (40\%). Kegunaan utama daun katuk dalam obat tradisional adalah sebagai penambah air susu ibu (ASI), yang secara turun temurun menyebutkan, bahwa daun katuk ini penggunaannya dengan cara dibuat sayur, dimakan setiap hari maka akanmemperbanyak dan memperlancar keluarnya ASI (Malik, 1997).

Daun katuk selain memilki kandungan gizi yang cukup tinggi juga terdapat senyawa flavonoid yang bersifat sebagai antioksidan dan besar manfaatnya bagi ibu menyusui diharapkan dapat menjadi produk olahan dendeng berbahan sayur ataupun pengganti daging bagi kaum vegetarian/ pola hidup yang berpantang pada makanan yang berasal dari tubuh mahluk hidup.

Tanaman katuk (Sauropus androgunus (L) Merr) mempunyai banyak manfaat dalam kehidupan sehari- hari. Hasil penelitian Kelompok Kerja Nasional Tumbuhan Obat Indonesia menunjukkan bahwa tanaman katuk mengandung beberapa senyawa kimia, antara lain alkaloid papaverin, protein, lemak, vitamin, mineral, saponin, flavonid dan tanin. Beberapa senyawa kimia yang terdapat dalam tanaman katuk diketahui berkhasiat obat (Rukmana, 2003).

Dengan

memperhatikan

kandungan gizi yang cukup tinggi serta adanya senyawa flavonoid dalam daun katuk serta manfaatnya yang baik bagi ibu menyusui, maka perlu dikembangkan olahan makanan daun katuk salah satunya menjadi dendeng. Pada penelitian Supardi (1999) pembuatan dendeng dengan bahan dasar jantung pisang dengan persentasi ikan teri yang digunakan yaitu dengan perbandingan $10 \% 20 \%$, 30\% dan 40\%. Angka persentase tersebut didapatkan dari uji coba persentase ikan teri $10 \%$, tetapi hasilnya kurang begitu maksimal. Sedangkan percobaan yang persentase ikan teri 20\%, 30\% dan 40\% sudah menunjukan hasil yang maksimal.

Pada pembuatan dendeng sayur bisa ditambahkan ikan lain selain ikan teri yaitu seperti ikan gabus. Menurut Ansar (2010) dalam bukunya menjelaskan bahwa sejak dahulu ikan gabus dipercaya dapat mempercepat penyembuhan luka sehingga dianjurkan untuk dikonsumsi pasien pasca operasi dan ibu-ibu sehabis melahirkan. Hal ini dikarenakan ikan gabus mengandung protein yang tinggi.

Jurnal Natur Indonesia III tahun 2001 yang ditulis oleh Tjipto leksono dan Syahrul, menambahkan bahwa kadar protein ikan gabus lebih tinggi dari pada ikan lele. Dahlan (2011) mengatakan dalam jurnalnya yang disitasi dari Mohsin dan Ambak, 1983 bahwa ikan gabus (channa striata) merupakan ikan 
yang mempunyai kandungan albumin yang cukup tinggi

Berdasarkan uraian latar belakang tersebut penulis tertarik untuk mengetahui pengaruh penambahan ikan gabus terhadap kualitas kimia dendeng daun katuk ditinjau dari kadar air, kadar protein, dan kadar vitamin $\mathrm{C}$ yang terdapat pada daun katuk dengan mengambil judul "Studi tentang penambahan ikan gabus (channa striata) terhadap kualitas kimia dendeng daun katuk (Sauropus Androgunus).

\section{Tujuan}

Tujuan dari penelitian ini adalah untuk mengetahui persentase ikan gabus yang tepat serta pengaruhnya terhadap karakteristik penerimaan konsumen dan kualitas kimia dendeng daun katuk (Sauropus Androgynus).

\section{Manfaat}

Manfaat dari penelitian ini adalah untuk memberikan pengetahuan kepada masyarakat mengenai manfaat daun katuk serta mengolah daun katuk menjadi makanan yang bernilai eknomis lebih tinggi.

\section{METODOLOGI PENELITAN}

\section{Bahan}

Bahan yang digunakan dalam pembuatan dendeng sayur daun katuk adalah daun katuk (Sauropus androgynus) sebanyak 100 gr, ikan gabus dengan level $(10 \%, 20 \%, 30 \%$, $40 \%$ ). Tepung tapioka 100 gr dan telur 60 gr. Bumbu yang digunakan antara lain : gula putih $10 \mathrm{gr}$, ketumbar $0,5 \mathrm{gr}$, bawang merah 15 gr, bawang putih 11 gr, garam $3 \mathrm{gr}$, daun jeruk 0,5 gr, jinten 0,1 gr, Adapun bahan yang digunakan untuk analisa meliputi analisa kadar air, protein dan vitamin $\mathrm{C}$ antara lain yaitu : aquades, $\mathrm{H}_{2} \mathrm{SO}_{4}, \mathrm{Na}_{2} \mathrm{SO}_{4}, \mathrm{HgO}, \mathrm{NaOH}$, $\mathrm{N}_{2} \mathrm{Na}_{2} \mathrm{~S}_{2} \mathrm{O}_{3}$, butiran zink, asam borat, $\mathrm{HCL}$, dan larutan dietil eter.

\section{Alat}

Adapun alat yang digunakan dalam pembuatan dendeng daun katuk adalah kukusan, panci, pisau, sendok, blender, oven, kompor, mangkok, talenan, loyang, timbangan, dan termometer. Sedangkan peralatan yang akan digunakan selama penelitian antara lain Oven, Cawan petri lengkap dengan tutupnya, penjepit cawan, timbangan analitik, desikator, tanur (bunsen), alat soxhlet lengkap dengan condenser, labu lemak, hot plate, labu kjeldahl, Erlenmeyer alat destilasi, Rotary evaporator, penangas air, labu berdasar bulat, Erlenmeyer, labu takar, labu pemisah, kondensor repluks allihn, adaptor, corong

\section{Metode Penelitian}

Metode yang digunakan adalah metode eksperimen yaitu mengadakan pengamatan langsung terhadap objekpenelitian. Rancangan yang digunakan dalam penelitian ini adalah Rancangan Acak Lengkap (RAL). Dimana terdiri dari 4 perlakuan dengan 3 kali ulangan yaitu:

$\mathrm{A}=$ Penambahan ikan gabus $10 \%$ dari berat daun katuk

$\mathrm{B}=$ Penambahan ikan gabus 20\%dari berat daun katuk

$\mathrm{C}=$ Penambahan ikan gabus $30 \%$ dari berat daun katuk

$\mathrm{D}=$ Penambahan ikan gabus $40 \%$ dari berat daun katuk

Dari hasil analisa data dilakukan analisis statistik apabila $\mathrm{F}_{\text {hit }}>\mathrm{F}_{\text {tabel }}$ (berbeda nyata) maka dilanjutkan dengan uji lanjut BNJ (Beda Nyata Jujur) pada taraf $5 \%$. 


\section{Pelaksanaan Penelitian}

Pengolahan dendeng sayur daun katuk (Sauropus Androgunus) terdiri dari 3 tahap proses yaitu : persiapan bahan daun katuk, persiapan ikan gabus, dan pembuatan dendeng. Untuk lebih jelas dapat dilihat pada uraian berikut ini:

\section{Persiapan Daun Katuk}

1. Penyotiran

Persiapan bahan dimulai dengan menyortir daun katuk, dimana daun katuk yang diambil adalah daun yang masih segar dan dipisahkan antara tangkai dan daunnya.

2. Pencucian

Daun katuk yang telah dipisahkan dari tangkainya dicuci untuk menghilangkan kotoran yang melekat pada daun.

3. Pengukusan

Pengukusan daun katuk (Sauropus Androgynus) dan dilakukan selama 10 menit dengan suhu dibawah $50^{\circ} \mathrm{C}$ untuk melunakkan tekstur daun katuk dan untuk mempermudah mempermudah dalam proses penggilingan.

4. Penggilingan/penumbukkan

Proses penumbukan bertujuan untuk memudahkan penyerapan bumbu pada saat kuring, daun katuk ditumbuk hingga seratnya pecah dan hancur. Pada proses penumbukan ini bumbu yang sudah dihaluskan juga dicampurkan (Tukhfah, 2000:20-21).

\section{Persiapan Ikan Gabus}

1. Sortasi

Sortasi bertujuan untukm memperoleh ikan yang masih segar dilihat dari bentuk fisiknya.
2. Penyiangan Ikan

Persiapan bahan selanjutnya adalah penyiangan ikan yaitu membuang kepala dan kotoran dalam perut ikan kemudian dibuang durinya.

\section{Pencucian}

Ikan yang telah disiang dicuci bersih dari kotoran yang melekat pada ikan.

4. Pemotongan/ Pengecilan Ukuran

Lalu dilakukan pengecilan ukuran dengan pemotongan/penggilingan sehingga diperoleh bahan dengan ukuran yang relatif kecil yang dapat memudahkan dalam proses pencampuran (Siagian, 1998). Selain itu, menurut Soeparno (1994), ukuran partikel yang relatif kecil memudahkan proses emulsifikasi dan diperoleh produk yang homogen.

\section{Pengukusan}

Pengukusan ikan dilakukan selama 15 menit dengan suhu $50^{\circ} \mathrm{C}$. Pengukusan bertujuan untuk menyatukan komponen adonan, memantapkan warna dan menonaktifkan mikroba (Koswara, 1995 ).

6. Penggilingan

Penggilingan bertujuan untuk diperoleh bahan dengan ukuran yang relatif kecil yang dapat memudahkan dalam proses pencampuran (Siagian, 1998). Selain itu, menurut Soeparno (1994), ukuran partikel yang relatif kecil memudahkan proses emulsifikasi dan diperoleh produk yang homogen.

\section{PembuatanDendeng}

1. Persiapan Bahan

Semua bahan disiapkan seperti daun katuk dan ikan gabus yang telah di kukus serta bumbu yang telah di persiapkan. 
2. Penumbukkan/Penggilingan

Proses penumbukan bertujuan untuk memudahkan penyerapan bumbu pada saat kuring, daun katuk ditumbuk hingga seratnya pecah dan hancur. Pada proses penumbukan ini bumbu yang sudah dihaluskan juga dicampurkan (Tukhfah, 2000:20-21).

3. Pencampuran

Semua bahan dicampur seperti ikan, daun katuk dan bumbu sesuai dengan perlakuan.

4. Proses Kuring atau Pembumbuan

Proses kuring dilakukan dengan tujuan memberi cita rasa tertent pada dendeng dengan cara bumbu dihaluskan, masukkan gula, garam yang kemudian dicampurkan dan direbus dengan menambahkan sedikit air $(250 \mathrm{cc}$ ) daun katuk. Diaduk-aduk hingga air menyusut.

\section{Pencetakan}

Daun katuk yang telah dibumbui dan dicampur dengan ikan kemudian dicetak diatas loyang dan membentuk lembaran dengan ketebalan 3 sampai $5 \mathrm{~mm}$. Pencetakan dimaksudkan untuk memberi bentuk pada produk sesuai dengan permintaan, disamping itu kenampakannya lebih baik (Moeljanto, 1982)

\section{Pengeringan}

Pengeringan merupakan suatu cara untuk menghilangkan kandungan air yang terdapat pada bahan makanan melalui proses pemanasan. Pengeringan dilakukan dengan alat yaitu cabinet drymerataudengan oven. Dengan cara memasukkan adonan dendeng yang sudah dicetak dalam loyang dan dikeringkan dengan suhu $50^{\circ} \mathrm{C}$ selama 1 jam. (Tukhfah, 2000:20-21).
7. Pengirisan atau pemotongan

Setelah proses pengeringan dengan menggunakan oven lalu dipotong atau diiris dengan panjang $7 \mathrm{~cm}$ dan lebar $5 \mathrm{~cm}$ dengan ketebalan $0,3 \mathrm{~mm}$

\section{Penggorengan}

Penggorengan merupakan proses termal yang umum dilakukan orang dengan menggunakan minyak atau lemak pangan. Bahan pangan yang digoreng mempunyai permukaan luar berwarna coklat keemasan.Warna yang muncul disebabkan karena reaksi pencoklatan (Maillard) (Ketaren, 1986). Reaksi Maillard terjadi antara protein, asam amino, dan amin dengan gula aldehida danketon, yang merupakan penyebab terjadinya pencoklatan selama pemanasan atau penyimpanan dalam waktu yang lama pada bahan pangan berprotein.

9. Tahap Pengemasan

Tahap pengemasan ini merupakan tahap akhir dari pembuatan dendeng daun katuk. Tahap ini meliputi proses pengemasan. Jika ingin dikonsumsi, dendeng daun katuk juga dapat digoreng terlebih dahulu sebelum dikonsumsi. Pengemasan dilakukan dengan menggunakan plastik yang tebal, minimal berukuran $0,5 \mathrm{~mm}$.

\section{Pengamatan}

Pengamatan yang dilakukan pada penelitian ini antara lain : uji kadar air, analisa kadar protein, analisa kadar vitamin $\mathrm{C}$, dan uji organoleptik.

\section{HASIL DAN PEMBAHASAN}

\section{Kadar Air}

Menurut De man (2007) menyatakan kadar air merupakan faktor 
utama yang mempengaruhi kualitas pangan. Istilah aktivitas air digunakan untuk menjabarkan air yang tidak terikat dalam bahan pangan. Kadar air dan aktivitas air berpengaruh besar terhadap laju reaksi kimia dan laju pertumbuhan mikroba dalam bahan pangan yang pada akhirnya berpengaruh dalam menentukan mutu dan umur simpan produk pangan selama penyimpanan, kadar air dan aktivits air akan mempengaruhi sifat sifat fisiko kimia, perubahan-perubahan kimia kerusakan biologis dan perubahan enzimatis terutama pada makanan yang tidak diolah.

Hasil penelitian menunjukkan bahwa penambahan ikan gabus dapat memberikan pengaruh yang berbeda sangat nyata pada taraf $5 \%$ terhadap kadar air dendeng daun katuk dimana Fhitung $(7,62)>F$ Tabel $(4,07)$. Rata-rata nilai kadar air dendeng daun katuk dan uji lanjut BNJ dapat dilihat pada Tabel 1.

Tabel 1. Rata-rata Kadar Air Dendeng Daun Katuk

\begin{tabular}{|c|c|}
\hline Perlakuan & Rata-rata \\
\hline $\mathrm{A}=$ penambahan ikan gabus $10 \%$ / berat daun katuk & $6,21 \mathrm{a}$ \\
\hline $\mathrm{B}=$ penambahan ikan gabus $20 \% /$ berat daun katuk & $7,32 \quad b$ \\
\hline $\mathrm{C}=$ penambahan ikan gabus $30 \% /$ berat daun katuk & $8,29 \quad \mathrm{~b} \mathrm{c}$ \\
\hline $\mathrm{D}=$ penambahan ikan gabus $40 \% /$ berat daun katuk & 9,19 \\
\hline
\end{tabular}

Keterangan: Angka-angka yang diikuti oleh huruf dan pada kolom yang sama berarti berbeda tidak nyata menurut uji BNJ taraf 5\%

Tabel 1 menunjukkan bahwa nilai rata-rata kadar air yang diperoleh dari hasil penelitian berkisar antara $6,21 \%$ sampai dengan 9,19\%. Kadar air terendah diperoleh dari perlakuan dendeng dengan penamban ikan gabus $10 \%$, sedangkan kadar air tertinggi diperoleh dari perlakuan dendeng dengan penambahan ikan gabus $40 \%$.

Nilai kadar air menunjukkan bahwa semakin tinggi tingkat penambahan ikan gabus maka nilai kadar air pada dendeng daun katuk semakin meningkat. Semakin tingginya kandungan air pada dendeng daun katuk disebabkan karena tingginya kandungan kadar air ikan yaitu 69,9\% / 100 gr bahan (suprapti, 2008). Hal ini sesuai menurut (Nurchotimah, 2002) penambahan konsentrasi residu daging ikan gabus sanggup mempengaruhi nilai kadar air. Kadar air yang dihasilkan cenderung meningkat dengan ditambahnya residu daging ikan gabus kedalam adonan.
Selain karena penambahan ikan gabus yang menyebabkan kadar air meningkat, hal lain yang menjadi penyebabnya adalah waktu pengukusan. Semakin lama waktu pengukusan yang digunakan, maka kadar air yang dihasilkan akan semakin meningkat. Hal ini sesuai menurut (Mushollaeni, 2006) waktu pengukusan yang semakin lama akan menaikkan kadar air karena dengan semakin lamanya waktu akan mengakibatkan semakin banyaknya uap air yang masuk sehingga kadar airnyapun semakin tinggi.

Dari Tabel 6 dapat dilihat bahwa nilai kadar air menunjukkan bahwa semakin besar penambahan ikan gabus, maka nilai kadar air pada dendeng daun katuk semakin meningkat. Pada perlakuan A memiliki rata-rata kadar air $6,21 \%$, perlakuan B 7,32\%, perlakuan C $8,29 \%$, perlakuan D 9,19\%. Dari ke empat perlakuan tersebut dapat dikatakan bahwa kadar air sesuai standar 
yang telah ditetapkan SNI yaitu maksimum sebesar $12 \%$.

\section{Analisa Kadar Protein}

Menurut Winarno (2008) Protein merupakan suatu zat makanan yang sangat penting bagi tubuh, karena berfungsi sebagai zat pembangun dan pengatur dalam tubuh.

Protein adalah salah satu biomakromolekul yang penting peranannya dalam makhluk hidup. Protein dapat memerankan fungsi sebagai bahan struktural karena seperti halnya polimer lain, protein memiliki rantai yang panjang dan juga dapat mengalami cross-linking dan lain-lain. Selain itu protein juga dapat berperan sebagai biokatalis untuk reaksi-reaksi kimia dalam sistem makhluk hidup suatu organisma. Suatu sistem metabolisme akan terganggu apabila biokatalis yang berperan didalamnya mengalami kerusakan (Hertadi, 2008).

Hasil penelitian kadar protein pada dendeng daun katuk menunjukkan bahwa penambahan ikan gabus memberikan pengaruh yang berbeda nyata pada taraf $5 \%$ terhadap dendeng daun katuk dimana Fhitung $(39,05)>\mathrm{F}$ tabel $(4,07)$. Rata-rata nilai kadar protein dendengdaun katuk dapat dilihat pada Tabel 2.

Tabel 2. Rata-Rata Kadar Protein Dendeng Daun Katuk

\begin{tabular}{|c|c|}
\hline Perlakuan & Rata-rata $(\%)$ \\
\hline $\mathrm{A}=$ penambahan ikan gabus $10 \% /$ berat daun katuk & $2,87 \quad \mathrm{a}$ \\
\hline $\mathrm{B}=$ penambahan ikan gabus $20 \% /$ berat daun katuk & 3,7 \\
\hline $\mathrm{C}=$ penambahan ikan gabus $30 \% /$ berat daun katuk & 4,3 \\
\hline $\mathrm{D}=$ penambahan ikan gabus $40 \% /$ berat daun katuk & 4,46 \\
\hline
\end{tabular}

Keterangan: Angka-angka yang diikuti oleh huruf dan pada kolom yang sama berarti berbeda nyata menurut uji BNJ taraf 5\%

Tabel 2 menunjukkan bahwa nilai rata-rata kadar protein yang diperoleh dari hasil penelitian berkisar antara $2,87 \%$ sampai dengan $4,46 \%$. Kadar protein terendah di peroleh dari perlakuan dendeng daun katuk dengan penambahan ikan gabus pada perlakuan A sebesar $10 \%$ yaitu $2,8 \%$. sedangkan kadar protein tertinggi diperoleh dengan penambahan ikan gabus pada perlakuan D sebesar $40 \%$ yaitu $4,46 \%$.

Nilai kadar protein menunujukkan bahwa semakin tinggi tingkat penambahan ikan gabus makan semakin meningkat pula kadar protein yang dihasilkan. Semakin tinggi kandungan protein pada dendeng daun katuk disebabkan karena tingginya kandungan kadar protein ikan gabus yaitu 25,5\% / $100 \mathrm{~g}$ bahan (Suprapti, 2008). Hal ini sesuai menurut penelitian Pradana (2012) menyatakan bahwa semakin banyak daging ikan yang ditambahkan maka semakin tinggi pula protein pada produk yang dihasilkan.

Hasil penelitian menunjukkan kadar protein tersebut belum memenuhi standar yang ditetapkan menurut SNI yaitu maksimal $30 \%$. Nilai kadar protein yang belum memenuhi standar disebabkan karena penggunaan bahan pembuatan dendeng yang berbeda, dimana biasanya dendeng dibuat dari daging yang memiliki kadar protein yang tinggi, sedangkan dendeng daun katuk terbuat dari sayuran yang memiliki kandungan protein sebesar 7,4\% / 100 gr bahan dan dengan ditambahkan dengan ikan gabus yang memiliki kadar 
protein sebesar 25,5 \% / 100 gr bahan masih belum memenuhi standar.

Dan dengan penambahan ikan gabus masih belum memenuhi standar dikarenakan penambahan ikan yang sedikit masih belum memenuhi SNI.

\section{Analisa Kadar Vitamin C}

Vitamin $\mathrm{C}$ adalah suatu senyawa organik yang terdapat didalam makanan dalam jumlah yang sedikit, dan dibutuhkan dalam jumlah yang besar untuk fungsi metabolisme yang normal. Vitamin dapat larut didalam air dan lemak. Vitamin yang larut dalam lemak adalah vitamin A,D,E,K dan yang larut dalam air adalah vitamin $\mathrm{B}$ dan $\mathrm{C}$ (Dorland, 2006).

Hasil penelitian kadar vitamin c pada dendeng daun katuk menunjukkan bahwa penambahan ikan gabus memberikan pengaruh berbeda tidak nyata pada traf 5\% terhadap dendeng daun katuk dimana Fhitung $(0,79)<$ Ftabel $(4,07)$. Rata-rata nilai kadar vitamin c dendeng daun katuk dapat dilihat pada Tabel 3.

\section{Tabel 3. Rata-rata Kadar Vitamin C Dendeng Daun Katuk}

\begin{tabular}{|c|c|}
\hline Perlakuan & Rata-rata \\
\hline $\mathrm{A}=$ penambahan ikan gabus $10 \%$ / berat daun katuk & 1,44 \\
\hline $\mathrm{B}=$ penambahan ikan gabus $20 \%$ / berat daun katuk & 1,36 \\
\hline $\mathrm{C}=$ penambahan ikan gabus $30 \%$ / berat daun katuk & 1,38 \\
\hline $\mathrm{D}=$ penambahan ikan gabus $40 \%$ / berat daun katuk & 1,36 \\
\hline
\end{tabular}

Tabel 3 menunjukkan bahwa nilai rata-rata kadar vitamin c yang diperoleh dari hasil penelitian berkisar antara $1,44 \%$ sampai dengan $1,36 \%$. Kadar vitamin $\mathrm{c}$ terendah diperoleh dari perlakuan penambahan ikan gabus sebesar 40\%, sedangkan nilai kadar protein tertinggi diperoleh dari perlakuan dengan penambahan ikan $10 \%$.

\section{Uji Organoleptik}

Penilaian organoleptik merupakan cara penilaian terhadap mutu atau sifat suatu produk dimana uji organoleptik meliputi warna, rasa, aroma dan tekstur pada suatu bahan pangan.

\section{Warna}

Warna merupakan komponen yang sangat penting dalam menentukan kualitas derajat penerimaan dari suatu bahan pangan. Penetuan mutu suatu bahan pangan tergantung dari beberapa faktor, tetapi sebelum faktor lain diperhitungkan secara visual faktor warna tampil lebih dulu untuk menentukan mutu bahan pangan (Winarno, 2004).

Hasil penelitian menunjukkan bahwa penambahan ikan gabus memberikan pengaruh berbeda tidak nyata terhadap warna dendeng daun katuk dimana Fhitung $(1,30)<$ Ftabel $(2,74)$.

Nilai rata-rata uji organoleptik warna yang diperoleh dari hasil penelitian berkisar antara 3,20\% $3,55 \%$. Warna yang paling disukai yaitu pada perlakuan $\mathrm{D}$ dengan penambahan ikan gabus sebanyak $40 \%$ / berat daun katuk, sedangkan warna yang kurang disukai yaitu pada perlakuan B dengan penambahan ikan gabus sebanyak 20\% / berat daun katuk.

\section{Aroma}

Menurut Winarno (2002), menyatakan bahwa bau makanan banyak 
menentukan kelezatan suatu bahan makanan. Pada umumnya bau yang diterima oleh hidung dan otak lebih banyak merupakan berbagai macam ramuan atau campuran bau utama yaitu asam, harum, tengik dan hangus.

Berdasarkan hasil penelitian menunjukkan bahwa perlakuan penambahan ikan gabus memberikan pengaruh berbeda tidak nyata pada taraf 5\% terhadap aroma dendeng daun katuk dimana $F_{\text {hitung }}(0,55)<F_{\text {tabel }}(2,74)$.

Nilai rata-rata organoleptik aroma yang diperoleh dari hasil penelitian berkisar antara 2,70\% - 2,90\%. Aroma yang paling disukai yaitu pada perlakuan D dengan penambahan ikan gabus sebanyak $40 \%$ berat daun katuk, sedangkan aroma yang yang kurang sukai yaitu pada perlakuan B dan C dengan penambahan ikan gabus sebanyak $20 \%$ dan $30 \%$.

\section{Rasa}

Rasa adalah faktor selanjutnya yang dinilai panelis setelah aroma. Rasa berbeda dengan bau dan lebih banyak melibatkan panca indera lidah. Rasa sangat sulit dimengerti secara tuntas oleh karena selera manusia sangat beragam. Umumnya makanan tidak hanya terdiri dari satu kelompok rasa saja, tetapi merupakan gabungan dari berbagai rasa yang terpadu sehingga menimnbulkan rasa makanan yang enak. Rasa merupakan salah satu faktor yang mempengaruhi penerimaan seseorang trhadap suatu makanan. Rasa secara umum dapat dibedakan menjadi asin, manis, pahit dan asam (Winarno,2002).

Hasil penelitian menunjukkan bahwa perlakuan penambahan ikan gabus memberikan pengaruh berbeda tidak nyata pada taraf 5\% terhadap dendeng daun katuk dimana $\mathrm{F}_{\text {hitung }}(0,21)$ $<\mathrm{F}_{\text {tabel }}(2,47)$.
Nilai rata-rata organoleptik rasa yang diperoleh dari hasil penelitian berkisar antara 2,65 \% - 2,80\%. Rasa yang paling disukai yaitu pada perlakuan B dengan penambahan ikan sebear $20 \%$, sedangkan rasa yang kurang disukai pada perlakuan $\mathrm{D}$ dengan penambahan ikan sebesar $40 \%$.

\section{Tektur}

Tekstur makanan dapat didefinisikan sebagai cara bagaimana berbagai unsur atau komponen dan unsur struktur di data dan digabungkan menjadi mikro dan makrostruktur. Tekstur makanan dapat dievaluasi dengan uji mekanika (metode instrumen) atau dengan analisis secara pengindraan. Dalam hal yang terakhir, kita menggunakan alat indera manusia sebagai alat analisis (Deman 1997).

Hasil penelitianmenunjukkan bahwa perlakuan penambahan ikan gabus memberikan pengaruh berbeda tidak nyata pada taraf $5 \%$ terhadap tekstur dendeng daun katuk dimana $F_{\text {hitung }}(1,29)<F_{\text {tabel }}(2,74)$.

Nilai rata-rata organoleptik tekstur yang diperoleh dari hasil penelitian berkisar antara 3,10\% - 3,45\%. Tekstur yang paling disukai yaitu perlakuan D dengan penambahan ikan gabus sebesar $40 \%$ pada dendeng daun katuk, sedangkan tekstur yang kurang di sukai yaitu perlakuan A dengan penambahan ikan gabus sebesar $10 \%$ pada dendeng daun katuk.

\section{KESIMPULAN DAN SARAN}

\section{Kesimpulan}

Berdasarkan hasil penelitian
dendeng daun katuk $\begin{array}{r}\text { (Sauropus } \\ \text { androgynus) bahwa perlakuan yang tepat }\end{array}$
terdapat pada perlakuan D dengan
penambahan ikan gabus (Channa


striata) dengan penambahan ikan gabus $40 \%$, dengan kadar air 9,19\%, kadar protein $4,46 \%$, kadar vitamin C $1,36 \%$. Dengan hasil uji organoleptik tingkat penerimaan konsumen warna 3,55\%, aroma 2,90\%, tekstur 3,45\%. Namun rasa konsumen lebih menyukai perlakuan B dengan penambahan ikan $20 \%$ yaitu $2,80 \%$.

\section{Saran}

Berdasarkan hasil penelitian perlu dilakukan penelitian lebih lanjut tentang proses pembuatan dendeng untuk mengetahui proses yang tepat sehingga dapat menghasilkan suatu olahan produk yang tinggi protein sehingga dapat memenuhi standar yang telahd itetapkan SNI No 01 - 2908 - 1992.

\section{DAFTAR PUSTAKA}

Agustini W. 2012. Pengaruh perendaman terhadap kualitas dendeng ikan lele. Jurusan Teknologi Jasa dan Produksi, Fakultas Teknik, Universitas Negeri Semarang.

Batari R. 2007. Identifikasi Senyawa Flavonoid Pada Sayuran Indigenous Jawa Barat. [Skripsi]. Bogor : Fakultas Teknologi Pertanian Institut Pertanian Bogor.

Dewi E N, Ibrahim R. 2008. Mutu dan daya simpan fillet dendeng ikan nila merah yang dikemas hampa udara dengan vacuum sealer skala rumah tangga. Jurnal Saintek Perikanan. 4. 1.

Husna N E. 2014. Dendeng Ikan Leubiem (Canthidermis Maculatus) dengan Variasi Metode Pembuatan, Jenis Gula dan Metode Pengeringan. Jurnal Teknologi dan Industri Pertanian Indonesia.

Isa M, Btb Z T, Harris A, Sugito, Herrialfian. 2015. Analisa proksimat kadar lemak ikan nila yang diberi suplementasi daun jaloh yang dikombinasi dengan kromium dalam pakan setelah pemaparan stres panas. Jurnal Medika Veterinaria. 9. 1.

Jahidin J P. 2012. Karakteristik Organoleptik Dendeng Batokok dengan Bahan Pengasap dan Lama Pengasapan yang Berbeda. Jurnal Ilmiah Ilmu-Ilmu Peternakan Vol. XV No.2

Kurniawan E. 2008. Karakteristik kimia dendeng daging sapi iris atau giling yang difermentasi oleh bakteri asam laktat lactobacillus plantarum 1b1. [Skripsi]. Bogor : Program Studi Teknologi Hasil Ternak Fakultas Peternakan Institut Pertanian Bogor.

Munawaroh S. 2010. Ekstraksi Minyak Daun Jeruk Purut (Citrus Hystrix D.C) Dengan Pelarut Etanol dan NHeksana. Jurnal Kompetensi Teknik 2.1

Pratiwi L. 2016. Studi Pemanfaatan Jantung Pisang dan Ikan Gabus Dalam Pembuatan Nugget. Program Studi Teknologi Hasil Pertanian, Jurusan Teknologi Pertanian, Fakultas Pertanian, Unversitas Riau.

Purnamasari E, Munawarah D S, Zam s i. 2013. Mutu kimi dendeng semi basah daging ayam yang direndam jus daun sirih (piper betle L) dengan konsentrasi dan lama perendaman berbeda. Jurnal Peternakan 10. 1.

Rachmawati D. 2006. Eksperimen Pembuatan Dendeng Bunga Pisang (Musa Paradisiaca). [Skripsi]. Semarang : Faklutas Teknik Universitas Negeri Semarang.

Satyaningtyas E, Estiasih T. 2014. Roti tawar laktogenik, perangsang asi, berbasis kearifan lokal daun katuk (sauropus androgynus (1.) merr). 
Malang : Jurusan Teknologi Hasil Pertanian, FTP Universitas Brawijaya Malang

Setiawan D W. 2013. Pemanfaatan Residu Daging Ikan Gabus (Ophiocephalus Striatus) Dalam Pembuatan Kerupuk Ikan Beralbumin. THPi Student Journal, Vol. 1 No. 1 pp 21-32

Suaidah F. 2014. Karakteristik Pengeringan Daun Jeruk Purut (Citrus Hytrix DC) di Bawah Paparan Gelombang Mikro. [Skripsi]. Jember : Fakultas Teknologi Pertanian Universitas Jember.

Subekti S. 2006. Penggunaan Tepung Daun Katuk dan Ekstrak Daun Katuk (Sauropus Androgynus L.Merr) Sebagai Substitusi Ransum yang Dapat Menghasilkan Produk Puyuh Jepang Rendah Kolesterol. Fakultas Peternakan Institut Pertanian Bogor.

Sugito. 2006. Penambahan Ikan Gabus (Ophiocephalus Strianus) Dan
Aplikasi Pembekuan Pada Pembuatan Pempek Gluten. Jurnal Ilmu-ilmu Pertanian Indonesia 8.2

Sulthoniyah S T M. 2013. Pengaruh suhu pengukusan terhadap kandungan gizi dan organoleptik abon ikan gabus (Ophiocephalus striatus). Jurnal thpi student. 1.1.

Suwandi R, Nurjanah, Winem M. 2014. Proporsi Bagian Tubuh dan Kadar Proksimat Ikan Gabus Pada Berbagai Ukuran. JPHPI. 17.1.

Tanti M Y. 2011. Pembuatan Dendeng Dengan Bahan Dasar Jantung Pisang [Tugas Akhir]. Jurusan Teknologi Jasa dan Produksi Fakultas Teknik Universitas Negeri Semarang.

Widodo I F. 2015. Karakteristik Bubuk Daun Jeruk purut (Cytrus Hystrix) Dengan Metode Foam Mat Drying. Palembang : Fakultas Pertanian Universita Sriwijaya [ 9 Oktober 2015]. 